\title{
Linguistic variation in english
}

Eliane da Rosa

elianedr19@gmail.com

Universidade Federal do Rio

Grande do Sul, Porto Alegre, Brasil.

\begin{abstract}
This paper aims to discuss the importance of teaching linguistic variation in English class. As language is considered a dynamic complex system (LARSEN-FREEMAN; CAMERON, 2007), which is built by its speakers in order to achieve an efficient communication, language may suffer processes of variation and change across the time. Variation is an inherent phenomenon to the grammar, which is acquired by the speaker through the lifetime (WEINREICH; LABOV; HERZOG, 1968). Because of those assumptions, this article seeks to demonstrate how relevant variation teaching is in English class, for awareness of linguistic variation may result in a better communicative competence and develop positive attitudes towards other nations and their cultures.
\end{abstract}

KEYWORDS: English teaching. Linguistic variation. Didactic activities. 


\section{INTRODUCTION}

Languages have been varying and changing along the centuries. Some languages die such as Celtic, Sanskrit and Hittite, while others evolve into another language(s) as a sign of being vivacious. One example of language evolving into another one was Latin, or rather, Vulgar Latin, from which originated a group of dialects called Romance. This, in turn, developed into the modern Romance languages: Italian, Portuguese, Spanish, French, and Romanian. In other words, it means that language is a dynamic system, which is in constant evolution to supply its speakers' communicative needs.

As language dynamicity results in linguistic transformations over time, the linguistic properties become unstable. However, it is interesting to mention that is not a problem for the speakers, because the heterogeneity is structured and does not cause any damage to the process of communication. Sociolinguistics, which is the field of Linguistics concerned about the study of language variation and change, can prove that variability (variation) follows some structural patterns enabling the speakers to understand each other during the communicative interaction.

Variation occurs within any language due to the way people use their language or because of the contact with other languages and cultures. Languages differ from each other with regard to different aspects of their structure, that is, in relation to their syntax, morphology, phonology, lexicon, and so on. According to Wolfram (2006, p. 333): "If structure is at the heart of language, then variation defines its soul".

As language is not a stable system, it is relevant to consider that linguistic variation makes part of the process of learning and acquisition. That is why variation must be taught independently if the language is L1 (mother tongue), L2 (second language) or FL (foreign language). For Weinreich, Labov and Herzog (1968), variation is considered an inherent phenomenon to the grammar, which is acquired by the speaker through the lifetime, or rather, variation makes part of the internalized knowledge of the speaker (MUNSON; EDWARDS; BECKMAN, 2005). Thereby it becomes essential to teach structures that are variable in the linguistic system, which can be motivated by factors found in the language structure or in the social structure of the speech community. Thus, based on those assumptions, this article seeks to discuss and demonstrate the importance of English language variation teaching along with some suggestions of activities to approach this topic in class.

\section{WHAT IS LANGUAGE VARIATION?}

According to Complexity Theory (LARSEN-FREEMAN; CAMERON, 2007), language is considered a dynamic complex system, which is in constant evolution to supply its speakers' communicative necessities. As speakers shape their language in order to achieve an efficient communication, language may suffer processes of variation and change across the centuries. 
changes it. Thus, if language is viewed as an open, continually evolving, system rather than a closed one, then concepts such as "end-state" grammars become anomalous since open systems are constantly undergoing change, sometimes rather rapidly (LARSENFREEMAN; CAMERON, 2007, p. 230).

In spite of languages have been changing, they continue organized and offering to their speakers the necessary resources to the circulation of meanings (FARACO, 2005, p. 14). It means that, although language is open to all kinds of influences and is constantly changing, it still by some manner maintains an identity as the "same" language (LARSEN-FREEMAN; CAMERON, 2007, p. 231). Those changes are slow and do not cause any damage to the structure of the language.

A speaker can choose the words and the structures (that are called linguistic conventions) to communicate a situation based on the previous use of these conventions in similar situations. The hearer accomplishes the same process of communication, but, in this case, the hearer's knowledge of previous uses of the conventions may not be the same as the speaker's. Then the new situation being communicated is unique and subject to different interpretations. During this procedure, language may undergo processes of linguistic variations.

In a complex system, there is «massive variation in all features at all times» (Kretzschmar, 2009: 8; see also de Bot et al., 2007). As applied to language use, the variation is attributable to the fact that language users dynamically adapt their language resources to the context, and the context is always changing. Because of the dynamic interplay between a language user and context, the separation between the two, while possible for analytic purposes, requires the untenable assumption that the two are independent (van Geert and Steenbeek, 2005) (LARSEN-FREEMAN, 2016, p. 20)

Therefore, variation is a result of the language use, i. e., individuals' linguistic interactions may transform and modify the system of language.

In the field of Sociolinguistics, Labov (1972) defines language as an instrument used by the members of a community with the purpose of communicating with one another. It is relevant to cite that language comes from a heterogeneous nature, not from a homogenous one as other linguists' view. According to the American sociolinguist (1969), variation must be viewed as an inherent part of the language, which can be observed in the vernacular of everyday life. In Labov's words, variation is conceived as two or more ways of saying the same thing. Weinreich, Labov and Herzog $(1968$, p. 187, 188), declares that:

The association between structure and homogeneity is an illusion. Linguistic structure includes the orderly differentiation of speaker and styles through rules which govern variation in the speech community; native command of the language includes the control of such heterogeneous structures. 
It is worth of mentioning that those linguistic characteristics also allow people to differentiate individuals, groups, communities, states and nations. Variability may arise in every level of a language grammar, in every variety of a language, in every style, dialect, and register of a language, in every speaker, and even in the same sentence in the same discourse (KRUG; SCHLÜTER, 2013). The examples below demonstrate variation occurring in different levels of the grammar in several languages:

a) lexical level: in Spanish-speaking countries, people call the seeds of a climbing plant, which are eaten as a vegetable, in different ways: for example, in Spain, this vegetable is called judías; in Argentina, porotos; and in Mexico, frijoles.

b) phonological level: in the South of Brazil, people pronounce the phoneme / I / as [ $t] \sim[\mathrm{w}]$ in syllable-final position: $c a[t] d a \sim$ ca[w]da; so[t] $\sim s o[w]$.

c) semantic level: in English, the word bitch means a female of dog an offensive way of referring to a woman.

d) morphosyntactic level: in French, there is the deletion of the negation particle ne in the negative structure "ne (proclitic) ... pas (general marker of negation)": Je ne vois pas Je $\emptyset$ vois pas.

e) pragmatic-stylistic level: in Brazilian Portuguese, according to the social interaction and the level of formality among the speakers, they may say "queiram se sentar, por favor" "vamo sentá aí, gente".

Thus, taking into consideration the premises that language is a social phenomenon, which is built by its speakers with the purpose of achieving an efficient communication, it is reasonable to assume that variation is everywhere, all the time. As Crystal (1963, p. 09) states: "A language is what all its users make it; it is a social, not just an academic phenomenon".

Moreover, other relevant issue is the necessity of teaching variation in language class, independently if the language is a mother tongue, a second, a third or a foreign one. It is through language variation teaching, teachers can help students to avoid pronunciation problems and misinterpretation in second/foreign language context, for example. many factors, including historical and social context, the communities we live in, the institutions and social organizations we participate in, and the backgrounds, cultures and identities of ourselves and others. Communication is a complex and nuanced behavior; it is both innate and learned. Being a good communicator 
depends on using language in acceptable, appropriate and effective ways (CHARITY HUDLEY; MALLINSON, 2014, p. 13-14)

In this case, lack of variation knowledge may lead to problems in terms of intelligibility ${ }^{1}$ and comprehensibility ${ }^{2}$ (EISENSTEIN, 1989; SMITH, 1992; CLOPPER; BRADLOW, 2008; BEINHOFF, 2014; MAHBOOB; BARRATT, 2014) during the communicative interaction due to the fact that among speakers (natives and nonnatives) of a language, there is variability in the way they use the target language. So, students must be aware that individual(s) or a speech community may adopt certain types of variants in their everyday speech and register. Conforming to Mahboob (2014, p. 6-7), "it is important to make our studentsaware of how language varies in these different contexts and provide them the linguistic tools necessary to navigate various contexts successfully".

Learners should learn that language is formed by different types of dialects (varieties) and not only by the one they learn in their textbooks, for example. Thus, it is recommendable that learners receive linguistic input not just from the textbooks they use in class, but from other sources such as chatting with native speakers, songs, movies, sitcoms, news, videos, online exercises, games, and so on. For the justification that language does not come from a homogenous nature, it is advisable to show for the students that variation exists and explains the kinds of phenomena they may face during the communicative interaction with foreign speakers.

Considering that variation makes part of the linguistic system and speakers shape its structure in order to supply their communicative needs, it is not possible to deny the relevance of teaching linguistic variation in English class.

\section{THE IMPORTANCE OF TEACHING LINGUISTIC VARIATION}

Weinreich, Labov and Herzog (1968) assume that variation is an inherent phenomenon to the grammar, which is acquired by the speaker during the lifetime. In other words, variation makes part of the internalized knowledge of the speaker (MUNSON; EDWARDS; BECKMAN, 2005), hence it becomes essential to teach structures that are variable in the linguistic system, which can be motivated by factors found in the language structure or in the social structure of the speech community.

As any other language, English presents variability in its linguistic system and due to this characteristic, students should learn it with the objective of understanding and being understood when they are interacting with foreign speakers. Besides that, it is notable to say that English is not a unique language, but rather it is composed by many varieties of English (British, American, Caribbean, Australian, and so on) that come from the same root. In relation to the English grammar, it is possible to notice variations occurring in all levels of the grammar:

film (UK) movie (US) 
sweet (UK) candy (US)

elevator (US) lift (UK)

\section{b) Phonological level:}

body: ['ba:di] ['ba:ri]

hold on: hol[d] on hol[ $\varnothing]$ on

Saturday: ['sætəder] ['sætəder] [særəreI]

c) Semantic level:

mouse $\rightarrow$ (animal) $\sim$ (computer device)

babe $\rightarrow \quad$ (a baby) (a word used to express affection) $~($ a word considered offensive if used by a man to a woman who he doesn't know)

\section{d) Morphosyntactic level:}

They $\emptyset$ walking too fast. $(A A E)^{3} \sim$ They are walking to fast.

$\downarrow$

(copula absence)

You were hungry and he were thirsty. You were hungry and he was thirsty.

$\downarrow$

(was/were generalization)

You don't have no money. You don't have any money.

$\downarrow$

(double negation)

e) Pragmatic level:

Would you like to drink some coffee, sir? Wanna drink coffee, man?

$\downarrow$

(formal way of addressing) (informal way of addressing)

Besides those examples, there are other kinds of linguistic variation phenomena such as phonological reduction, which is very common in English. The forms below are examples of phonological reduction: 


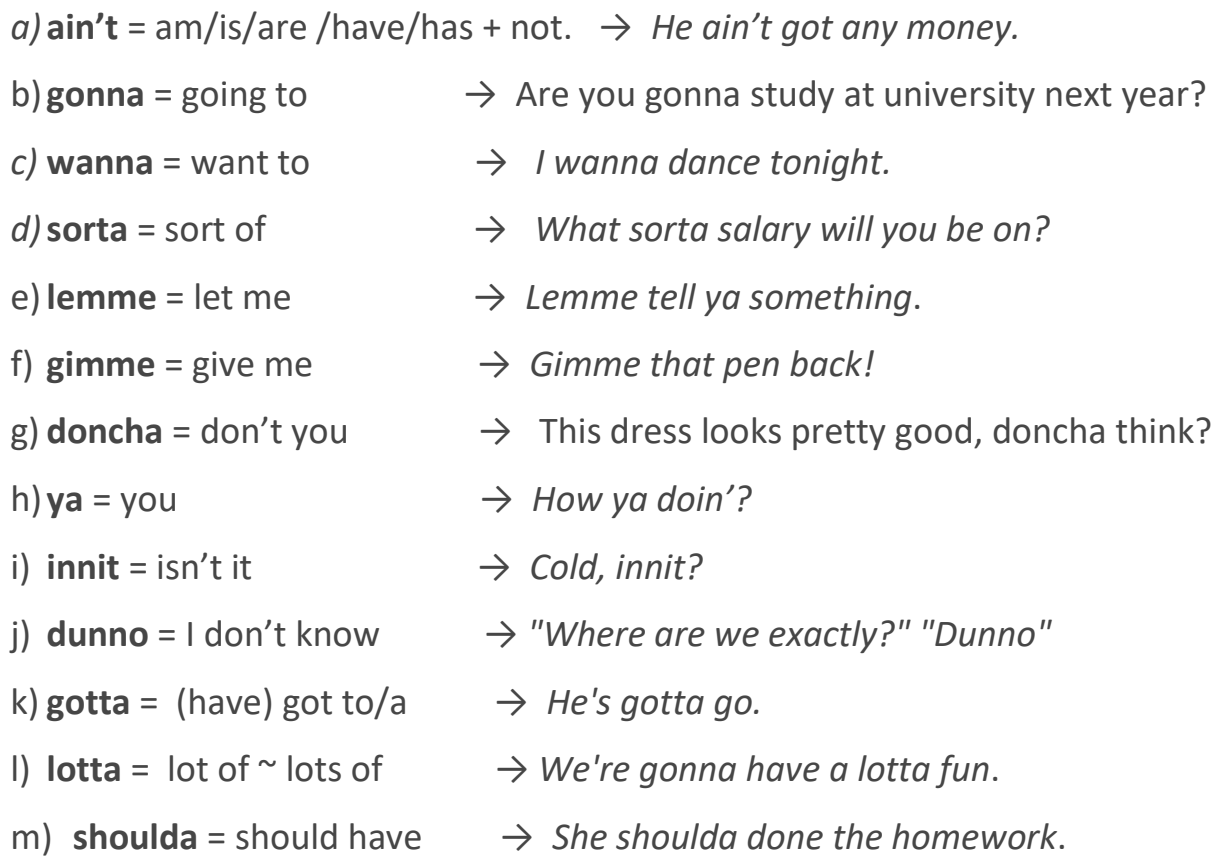

Along the last decades, Sociolinguistic researches have demonstrated that heterogeneity and variability are present in the structure of all languages around the world. Therefore, it is reasonable to conclude that learning language variation is important and necessary to develop students' communicative competence in English. When learners interact with native and non-native speakers of a language they face different forms of saying the same thing. As all aspects of grammar (phonemes, morphemes, syntactic structures, and meanings) are subject to variation, there are several factors that influence and motivate variability such as age, social class, culture, style, among others. Variation may be classify into phonological, semantic, syntactic, regional, age-based, genderrelated, stylistic, etc., i. e., language varies from person to person, from region to region, and across situations. And because of issues students should learn how language functions as well as being aware of the existence of the linguistic and cultural diversity in English.

Teaching English language through a pedagogy centered on the standard variety, it is not advisable nowadays. Teachers must prepare students for being competent communicators in English and promote cultural and linguistic diversity learning in the classroom. Furthermore, this awareness of variation may help and stimulate students to be tolerant and adopt positive attitudes with regard to other cultures and nations, which is an issue under discussion around the world nowadays. When people are in contact with other nations, the learners' lack of knowledge in relation to their style of life, culture and speech may cause problems in misunderstanding and/or lead to prejudice towards those people. As educators/teachers, we have the responsibility to raise students' awareness with respect to tolerance and respect to the socio-cultural linguistic differences they will face during the communicative interaction with foreign speakers. In summary, learning linguistic variation is crucial because language is in constant evolution and shaped by its use in different contexts. 


\section{SUGGESTIONS OF ACTIVITIES TO APPLY IN ENGLISH CLASS}

In order to teaching linguistic variation in English class, teachers can formulate didactic activities and exercises using songs, news, sitcoms, TV series, movies, videos, games, etc. as tools of learning. Here, it will be suggested four types of exercise to apply in class.

The first suggestion of activity is concerned with songs. In this exercise, teachers may use the lyrics of a song to talk about processes of phonological reduction. In this exercise, students are invited to listen to this song and underline the forms, which are in process of phonological reduction in English as can be seen in Table 1:

Table 1. Activity with song.

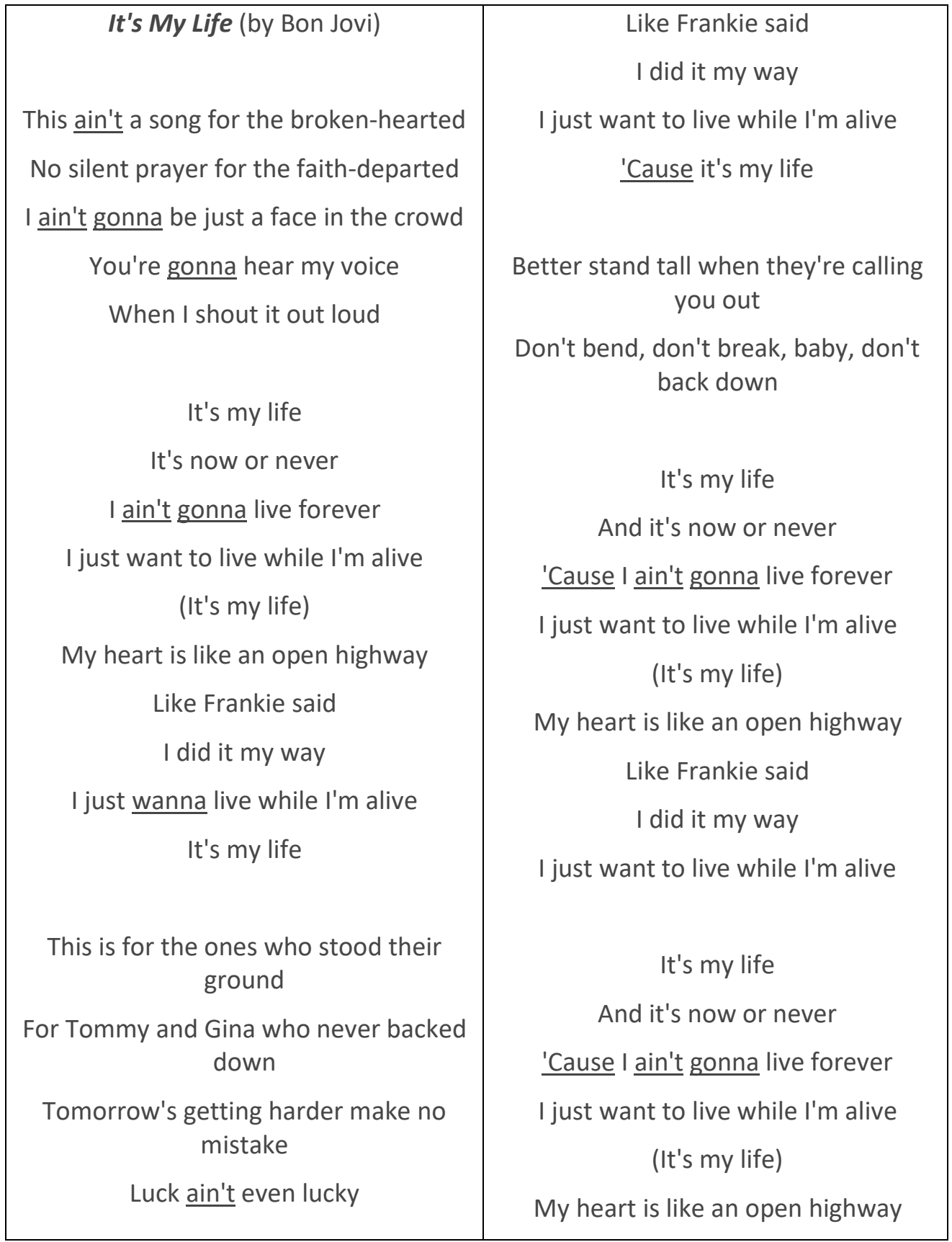


Got to make your own breaks

It's my life

And it's now or never

I ain't gonna live forever

I just want to live while I'm alive

(It's my life)

My heart is like an open highway
Like Frankie said

I did it my way

I just want to live while I'm alive

'Cause it's my life!

After this procedure, it is advisable to check the students' answers through a discussion with the whole group aiming to develop variation awareness and to explain why those forms are the way they are. Along this discussion, it is also possible to ask students to mention other types of forms in phonological reduction that they know or adopt in their everyday speech. In this case, teachers may use the whiteboard to write those examples and ask them if they remember other songs with the variants they have cited.

The second suggestion is related to music video. Teachers may use the video "let's call the whole thing off" (by Ella Fitzgerald and Louis Armstrong) to demonstrate variation in the level of pronunciation. To start the activity, teacher should ask students what comes to their minds when they read the title of the song. After this debate, students are invited to watch the video and tell what is happening with the couple, or rather, what is the reason of a possible breaking up between them.

Figure 1. Video "let's call the whole thing off".

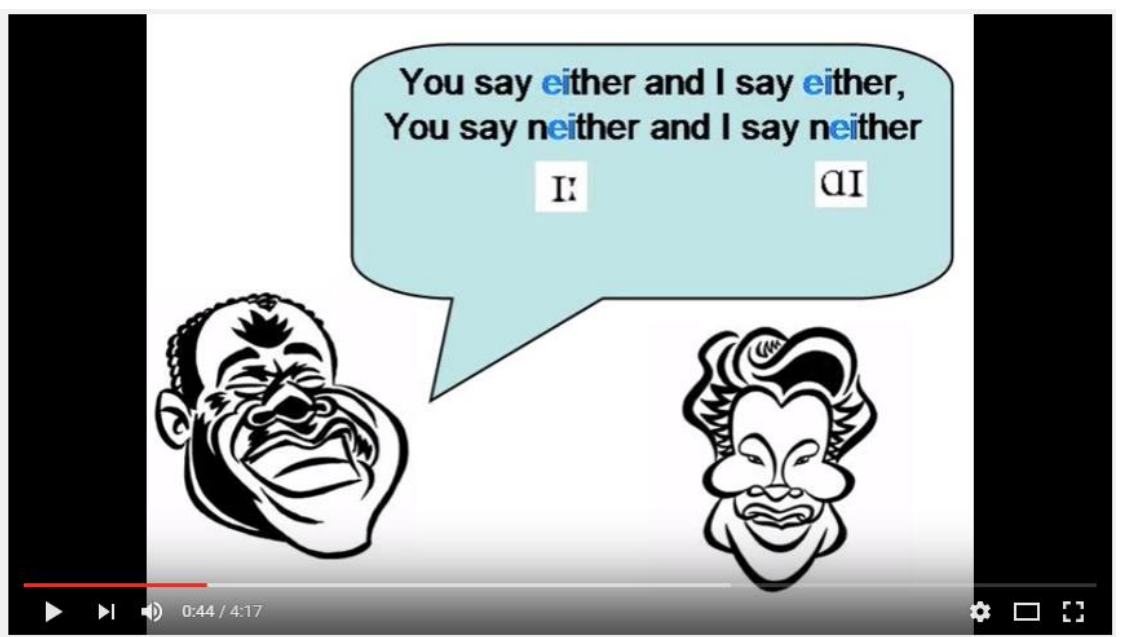

According to the story (lyrics), the cause of the possible end of the relationship is linguistic variation. So, with this kind of exercise, students are allowed to observe how it is important to learn pronunciation in order to avoid misinterpretation and problems during the sounds production, factors so relevant to achieve effective intelligibility and comprehensibility during the communication in a foreign/second language setting. Here, teachers have an opportunity to discuss 
about accents, i. e., the different ways of producing speech (DERWING; MUNRO, 2009) and how important is being aware of those differences with the purpose of promoting a better comprehensibility and intelligibility among users of a language.

The third suggestion is with respect to TV series. In this case, teachers may ask students to sit in pairs and watch the video "Friends: How to quit a gym membership" ${ }^{\prime 5}$ with subtitles or not in conformity with their proficiency level.

Figure 2. Video "Friends: how to quit a gym membership".

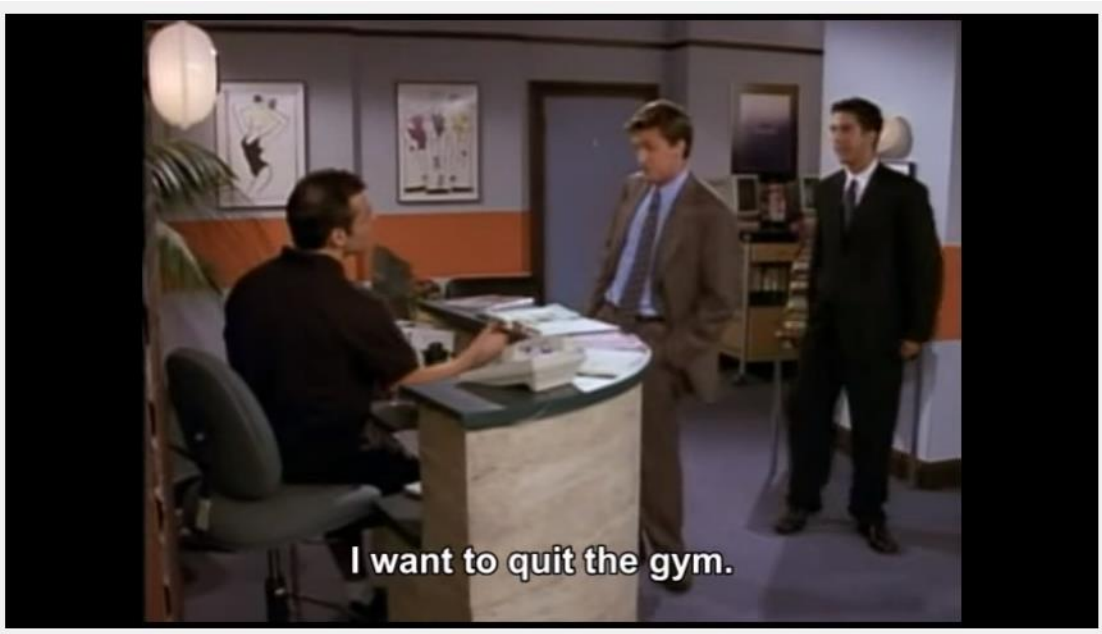

While they are watching the video, the students should mark a tick $(\mathrm{V})$ in the form (see Table 2), which represents the characters' pronunciation in relation to the underlined sounds and words:

Table 2. Pronunciation exercise.

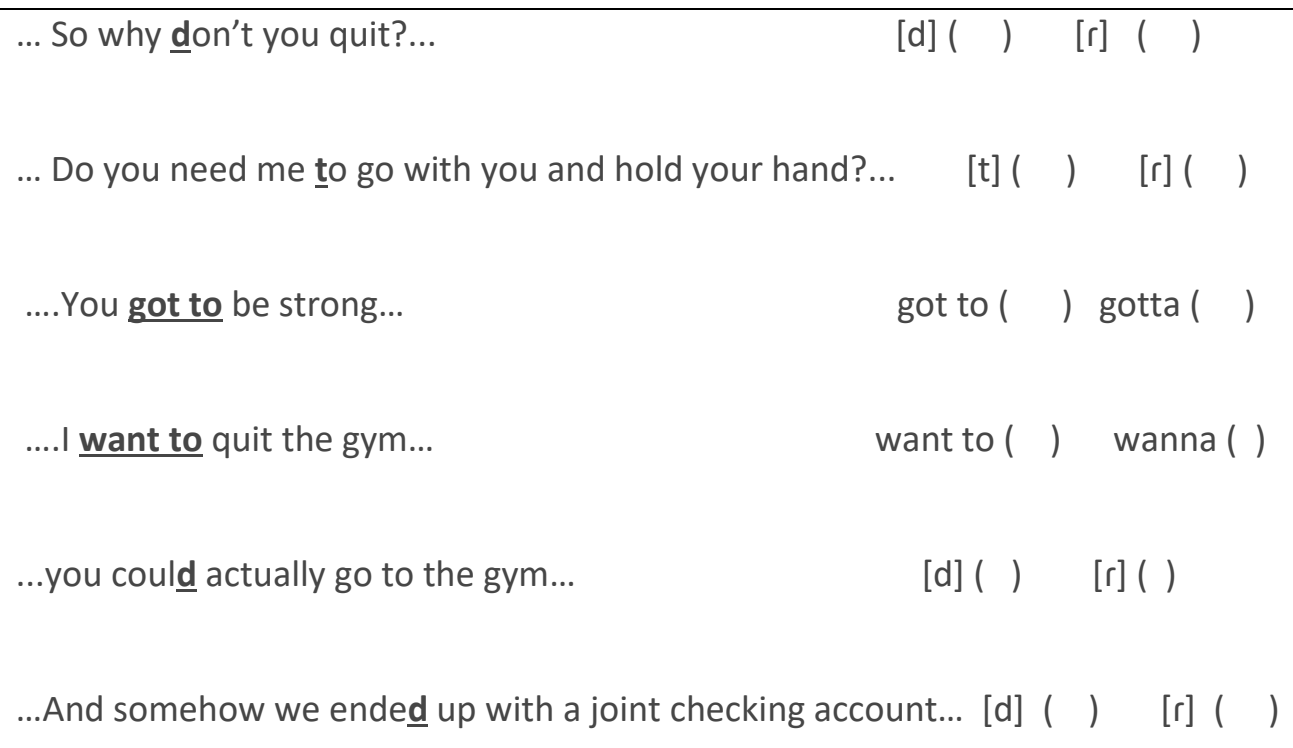

As soon as they finish the exercise, teacher should check theirs answers playing the video again and pausing in the excerpts they had to observe. This activity is good to demonstrate the way North American speakers produce the / $t$ / and $/ d /$ between vowel sounds in the standard variety. 
The fourth suggestion is a memory game, in which students should find the other form of saying the same thing in respect to lexical items as it is shown in Figure 3:

Figure 3. Memory game images.
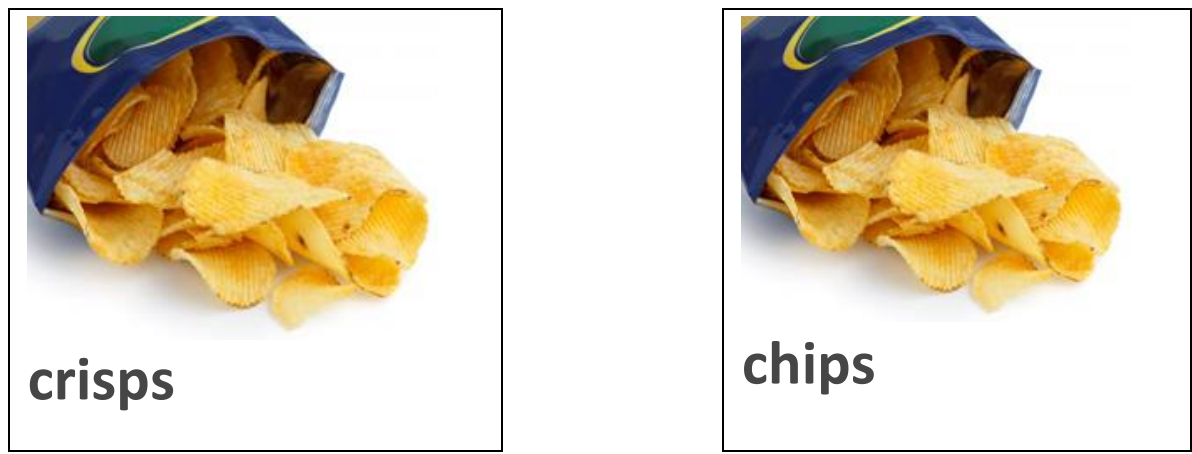

Through this game, students can improve vocabulary and discover different possibilities of saying the same lexical item according to the region English native and non-native speakers live in. With this activity, it is possible to raise the awareness that lexical choices are influenced by language use along with age and geographic location. In addition, it would be very valuable to ask students to research about lexical variation in terms of differences in meaning in order to present in class. For example, the word vest, in the United States (US), means "a piece of clothing that covers the upper body but not the arms and usually has buttons down the front, worn over a shirt", while, in the United Kingdom (UK), the same word signifies "a piece of underwear worn under a shirt, etc. next to the skin". By means of this activity, students are motivated to engage in their own process of language learning and became aware of this kind variation in meaning. As a result, communication problems and misunderstandings may be avoided. This is a nice illustration of how noteworthy linguistic variation teaching is useful for language learning.

The suggestions presented in this section aim to help teachers to have an idea of how they can create activities and exercises in order to teach variation in English class. When students have the opportunity of learning variability, they improve their communicative competence because they start developing their consciousness of that language is not a stable and homogenous system. Thus, students begin thinking about the structure of the language and how it works functionally. Furthermore, it is notable to mention the relevance of experiencing the different ways speakers use their languages. For instance, in the United States, Americans refer to a generic term for a sweetened carbonated beverage in four different ways: soda, pop, soft drink and coke. If learners do not know those possibilities, they might think that the word Coke refers only to the Cocacola liquid and not to any soft drink.

Learning linguistic variation brings benefits for language students because learners are encouraged to explore issues related to socio-historical and cultural aspects such as the relation between language and society, what factors may interfere in the language use and identity formation of a nation and why users of a language choose certain variant(s) rather than other(s). And there is also another important benefit from this knowledge, the learners' development of positive attitudes towards the target language community. 
FINAL CONSIDERATIONS

According to Larsen-Freeman and Cameron (2007), languages are viewed as complex and dynamic systems, which are continually being transformed by their use. Then, due to this constant evolution and adaptation, languages may suffer processes of linguistic variation and change across the time to supply their speakers' communicative needs. Taking into consideration the dynamicity of the languages and that they are built by their speakers, it is reasonable to say that variation is a relevant issue to be discussed in language class.

As variation is an inherent phenomenon to the grammar (WEINREICH; LABOV; HERZOG, 1968), which is acquired by the speaker during lifetime. As a consequence, variation makes part of the internalized knowledge of the speaker (MUNSON; EDWARDS; BECKMAN, 2005). In the light of this, this discussion has concluded that linguistic variation must be taught in language class in order to help students to develop their communicative competence and their linguistic awareness about the linguistic system and how it works functionally. When learners have contact with foreign speakers, it is inevitable to face with language variation and they must be prepared to deal with the different ways of using the target language as well as having positive attitudes towards the socio-cultural differences of those nations. 


\section{Variação linguística no inglês}

\section{RESUMO}

Este trabalho tem por objetivo discutir a importância de ensinar variação linguística na aula de inglês. Já que a língua é considerada um sistema complexo e dinâmico (LARSENFREEMAN; CAMERON, 2007), o qual é construído pelos seus falantes com o intuito de realizar uma comunicação eficiente, a língua pode sofrer processos de variação e mudança ao longo do tempo. A variação é um fenômeno inerente à gramatica, que é adquirido pelo falante ao longo da vida (WEINREICH; LABOV; HERZOG, 1968). Por causa destas premissas, este artigo busca demonstrar quão relevante é o ensino de variação na aula de inglês, pois a consciência da variação linguística pode resultar em uma melhor competência comunicativa e a desenvolver atitudes positivas para com outras nações e suas culturas.

PALAVRAS-CHAVE: Ensino de inglês. Variação linguística. Atividades didáticas. 


\section{NOTAS}

${ }^{1}$ Intelligibility is considered the degree that listener understands the speaker's intended message (DERWING; MUNRO, 2015)

${ }^{2}$ Comprehensibility is considered a measure of how easy or difficult it is for a listener to understand a speaker's productions (DERWING; MUNRO, 2015).

${ }^{3}$ African American English.

${ }^{4}$ Available at: <https://www.youtube.com/watch?v=Dg2HKMFsers>.

${ }^{5}$ Available at: <https://www.youtube.com/watch?v=oh8PFsOLTKc $>$.

\section{REFERENCES}

BECKNER, Clay; ELLIS, Nick C.; BLYTHE, Richard; HOLLAND, John; BYBEE, Joan; KE, Jynyun; CHRISTIANSEN, Morten H.; LARSEN-FREEMAN, Diane; CROFT, William; SCHOENEMANN, Tom. Language is a Complex Adaptive System - Position Paper. Language Learning, v. 59, supl. 1, p. 1-26, 2009.

BEINHOFF, Bettina. Perceiving intelligibility and accentedness in non-native speech: a Look at proficiency levels. Proceedings of the International Symposium on the Acquisition of Second Language Speech, Concordia Working Papers in Applied Linguistics, 5, 2014.

CHARITY HUDLEY, Anne H.; MALLINSON, Christine. We do languages: English language variation in the secondary English classroom. New York: Teachers College Press, 2014.

CLOPPER, Cynthia G.; BRADLOW, Ann R. Perception of dialect variation in noise: intelligibility and classification. Lang Speech, vol. 51, Issue 3, p. 175-198, 2008.

CRYSTAL, David. A language must change, to keep pace with society. Liverpool Daily Post: Thursday, May 16th, 1963. p. 09-10. Available at:

<http://www.davidcrystal.com/DC articles/English110.pdf $>$. Date of access: March 4th, 2011.

DERWING, Tracy M..; MUNRO, Murray J.. Putting accent in its place: rethinking obstacles to communication. Language Teaching, 42, p. 476-490, 2009.

. The interface of teaching and research: what type of pronunciation instruction should L2 learners expect? In: LUCHINI, P. L.; GARCÍA JURADO, M. A.; ALVES, U. K. Fonética y fonología: articulación entre enseñanza e investigación. Mar del Plata: Universidad Nacional de Mar del Plata, 2015, p. 14-26. 
EISENSTEIN, Miriam R. Dialect variation and second-language intelligibility. In: EISENSTEIN, Miriam R. (eds.). The dynamic interlanguage: empirical studies in second language variation. New York: Springer Science/Business Media, 1989.

FARACO, Carlos Alberto. Lingüística histórica: uma introdução ao estudo da história das línguas. São Paulo: Parábola Editorial, 2005[1950].

FINEGAN, Edward. Language: its structure and use. $5^{\text {th }}$ ed. Boston: Thomson Wadsworth, 2008.

KRUG, Manfred; SCHLÜTER, Julia (eds). Research methods in language variation and change. New York: Cambridge University Press, 2013.

LABOV, William. Contraction, deletion and inherent variability of the English copula. Language, vol. 45, no 04, p. 715-762, 1969.

Press, 1972.

Sociolinguistic patterns. Philadelphia: University of Pennsylvania

LARSEN-FREEMAN, Diane. A successful union: linking ELF with CAS. 2016. Available at: file://C:/Users/acer/Downloads/607-1208-1-SM.pdf. Date of access: 04/09/2017.

LARSEN-FREEMAN, Diane; CAMERON, Lynne. Complex systems and applied linguistics. International Journal of Applied Linguistics, 17(2), p. 226-239, 2007.

MAHBOOB, Ahmar. Englishes in multilingual contexts. In: MAHBOOB, Ahmar; BARRATT, Leslie (eds.). Englishes in multilingual contexts: language variation and education. New York/London: Springer, 2014, p. 1-14.

MAHBOOB, Ahmar; BARRATT, Leslie (eds.). Englishes in multilingual contexts: language variation and education. New York/London: Springer, 2014.

MUNSON, B.; EDWARDS, J.; BECKMAN, M.E. Phonological knowledge in typical and atypical speech-sound development. Topics in Language Disorders, v. 25, 2005, p. 190-206.

SMITH, L. E.. Spread of English and issues of intelligibility. In: KACHRU, B. B. (ed.). The other tongue: English across cultures. Urbana: University of Illinois Press, 
WIENREICH, Uriel; LABOV, William; HERZOG, Marvin. Empirical foundations for a theory of language change. In: LEHMANN, Paul; MALKIEL, Yakov (eds.). Directions for historical linguistics. Austin: University of Texas Press, 1968, p. 95-188.

WOLFRAM, W. Variation and language: overview. In: BROWN, K. (ed.).

Encyclopedia of languages and linguistics II. Oxford: Elsevier, 2006, p. 333-40.

Recebido: 16 ago. 2016

Aprovado: 01 set. 2017

DOI: 10.3895/rl.v19n25.4523

Como citar: ROSA, Eliane da. Linguistic Variation in English. R. Letras, Curitiba, v. 19, n. 25, p. 35-50,

jan./jun. 2017. Disponível em: <https://periodicos.utfpr.edu.br/rl>. Acesso em: XXX

Direito autoral: Este artigo está licenciado sob os termos da Licença Creative Commons-Atribuição 4.0 Internacional.

(c) (i) 